
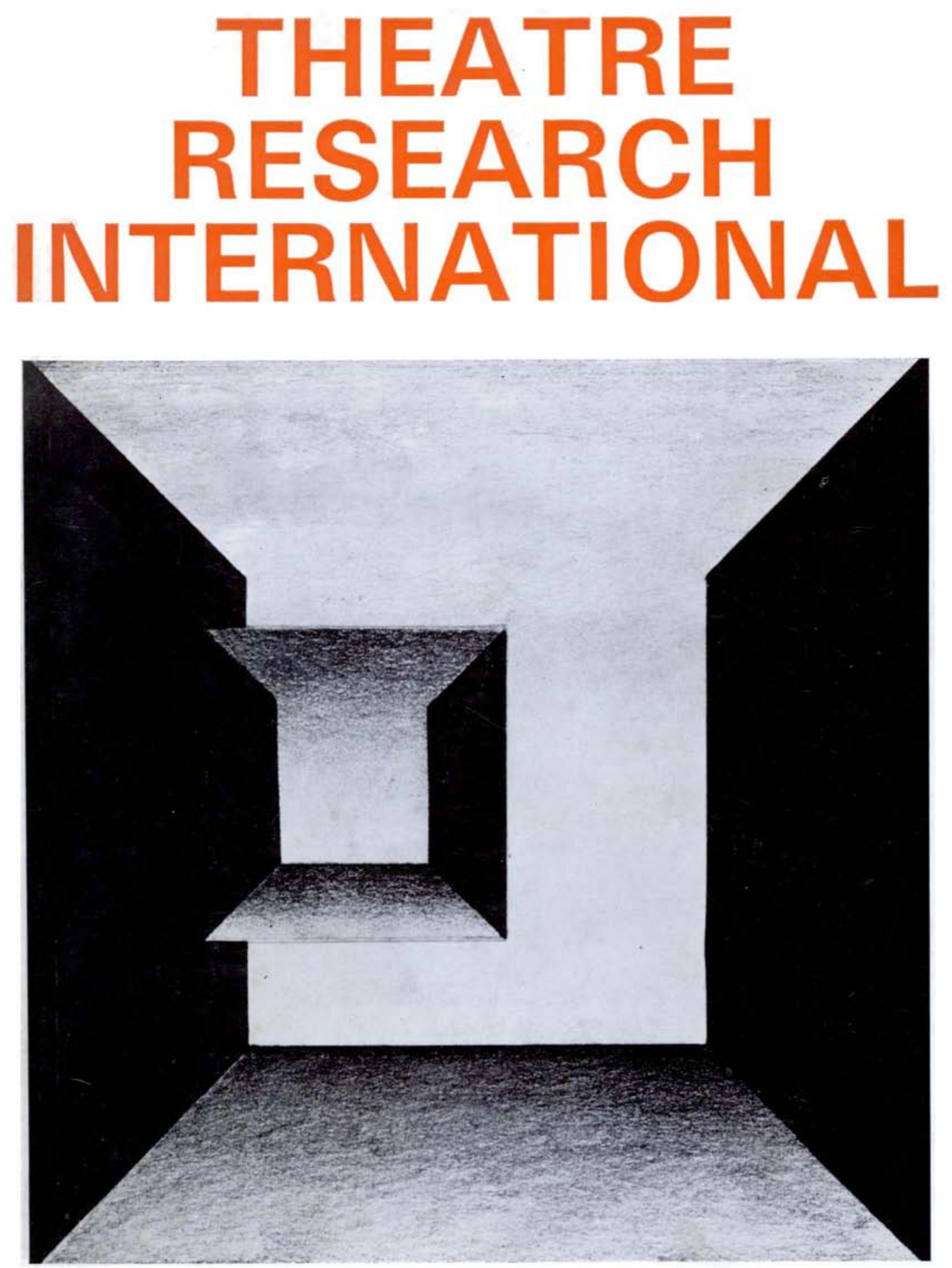

NEW SERIES VOLUME II NUMBER 2 FEBRUARY 1977

Oxford University Press in association with the

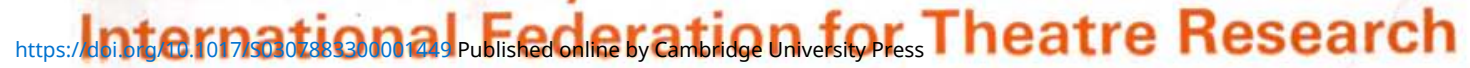




\section{Oxford Journals}

\section{British Journal of Aesthetics}

\section{Editor: Harold Osborne}

The British Journal of Aesthetics, a journal for the understanding of art and its appreciation, and for the principles of criticism, is published for The British Society of Aesthetics. Its main purpose is to provide a medium for the study of the philosophy of art and the principles of aesthetic appreciation and judgment, and this it does in the context of all the arts. As well as general aesthetics, experience of both fine and applied art is examined from the point of view of the psychologist, the sociologist, the historian, the teacher and the general critic.

Published Winter, Spring, Summer and Autumn.

Annual subscription: $£ 7.50$ ( $\$ 22.00$ by air-surface post to U.S.A.)

\section{Review of English Studies}

\section{Editor: J. B. Bamborough}

A journal concerned with English literature and the English language from the earliest period up to the present day. Each issue contains articles, notes, reviews of recent books, and a summary of periodical literature. The emphasis in the articles and notes is on historical scholarship rather than interpretative criticism, but it is hoped that the discovery of new facts or material (or the reconstruction of known facts and material) will modify criticism of a writer or a work, and sometimes lead to a fresh evaluation or interpretation. Reviews are mainly of books in English, but works in the other major European languages are reviewed from time to time.

Published February, May, August and November.

Annual subscription: $£ 12.00$ (U.K. $£ 9.00$ U.S.A. $\$ 27.50$ inc. air-surface post)

For an inspection copy, or to take out a subscription, please contact your regular bookseller or write to: Journals Manager, Oxford University Press, Press Road, Neasden, London NW10 0DD.

\section{Oxford University Press}




\section{Contents}

\section{ARTICLES}

Michael Walton, Financial Arrangements for the Athenian Dramatic Festivals

John OrRell, A New Witness of the Restoration Stage, 1670-1680

Mrchael R. Booth, East End and West End: Class and Audience in Victorian London

Klaus Neirendam, The Second Staging of Peer Gynt, 1886

Michael Jamieson, An American Actress at Balmoral

Annabelle Henkin Melzer, Homage to Robert Aron, 1898-1975

Patrick Marsh, Jeanne d'Arc During the German Occupation

\section{REVIEWS}

Joanne Spencer Kantrowitz, Dramatic Allegory: Lindsay's Ane Satyre of the Thrie Estaitis (Matthew P. McDiarmid)

Gerald Gillespie (Editor, translator), Ludwig Tieck: Der gestiefelte Kater (John Prudhoe)

J. S. Bratton, The Victorian Popular Ballad; George Speight, Bawdy Songs of the Early Music Hall (David Mayer)

J. G. TREWIN, The Edwardian Theatre (Jan McDonald)

John H. ReILly, Arthur Adamov (J. McCormick)

Frank Popper, Art-Action and Appreciation (André Veinstein) 


\title{
EDITORS
}

\author{
J. F. Arnott \\ Professor of Drama \\ University of Glasgow \\ K. R. RICHARDS \\ Reader in Drama \\ Victoria University of Manchester
}

ASSOCIATE EDITOR, FRENGH LANGUAGE

Glaude Schumacher, Department of Drama, University of Glasgow

\author{
ASSISTANT EDITOR \\ Janice McCallum, Department of Drama, University of Glasgow
}

EDITORIAL BOARD

Glynne Wickham, Professor of Drama, University of Bristol (Chairman)

E. Alkazi, Director, National School of Drama and Asian Theatre Institute, New Delhi

Toshio Kawatake, Professor of Drama, Waseda University, Tokyo

Thomas F. Marshall, Professor of English, Kent State University, Ohio/American Society for Theatre Research

Klaus Neiiendam, Teatervidenskabelige Institut, University of Copenhagen/Teatermuseet Museum, Copenhagen

Jack Reading, Society for Theatre Research, London

André Veinstein, Professor of Drama, University of Paris VIII/Président, Section Internationale des Bibliothèques et Musées des Arts du Spectacle

Theatre Research International is the continuation of Theatre Research/Recherches Théatrales. The change of title marks the assumption by Oxford University Press of responsibility for publication. The new title also indicates that the association with the International Federation for Theatre Research/Fédération Internationale pour la Recherche Théatrale, which founded the journal, will remain. Bilingualism has not been entirely abandoned: contributions appear only in English, but articles are provided with résumés in French. The field continues to be the historical, critical and theoretical study and documentation of drama, conceived as the art of the theatre.

New readers might like to learn that the motif on our cover was designed by Josef Svoboda for Theatre Research/Recherches Théatrales in 1966 and presented to the International Federation for Theatre Research/Fédération Internationale pour la Recherche Théâtrale.

Grateful acknowledgement of financial support is made to the Universities of Birmingham, Bristol, Glasgow, Lancaster, Liverpool, Manchester, Sussex, the University College of Swansea, and to the Toneelmuseum, Amsterdam.

MSS and books for review should be sent to the Assistant Editor, Janice McCallum, Department of Drama, University of Glasgow, Glasgow G12, Scotland, U.K.

Theatre Research International is published three times a year, in October, February and May at a price of $£ 8.00$ (U.K. $£ 7.00$, U.S.A. $\$ 18.00$ ) p.a., with single issues at $£ 2.70$ (U.S.A. \$6.75). All dispatches post free (by accelerated surface post to the U.S.A.). Orders should be placed with a bookseller or sent direct to Journals Subscription Department, Oxford University Press, Neasden Lane, London NW10 $0 D D$.

(C) Oxford University Press 1977

ISSN $0307-8833$

Printed in Great Britain by Robert MacLehose \& Company Limited

Printers to the University of Glasgow 